\title{
Crude Oil Price Fluctuation And Inflation In Nigeria
}

\author{
Apere, ThankGod Oyinpreye (Ph.D) \\ Department of Economics, Niger Delta University \\ Wilberforce Island, Bayelsa State, Nigeria
}

\begin{abstract}
This research empirically investigated the relationship between inflation and oil price fluctuations in Nigeria with quarterly data over the period 1980:1 to 2015:4.Using secondary data obtained from the Central Bank of Nigeria (CBN) Statistical Bulletin 2015 and Energy Information Administration (EIA) short-term outlook, December, 2016. Vector autoregressive model econometric technique was adopted in analysing the data for this study with the following analysis carried out; the Lag length selection, VAR stability tests, VAR LM test for serial correlation, the Impulse Response Function and the Forecast Error Variance Decomposition. The study revealed that the response of inflation to oil price fluctuation is that as oil prices falls inflation fall also and a stable and positive oil price results in a stable negative inflation rate, thus the relationship between them( inflation and oil price fluctuation) is negative This study therefore recommends that the cost channels transmission should be weakened by further diversification of the Nigeria economy and enhancement of import substitution strategies. To facilitate the monetary authority in achieving lower inflation and stable economic growth targets counter-cyclical fiscal policies and effectively binding fiscal rules should be formulated and implemented.
\end{abstract}

Keywords: Oil Price Fluctuation, Inflation Trends, Oil Price Shock, Fiscal Channel

\section{INTRODUCTION}

The trends in inflation rates in Nigeria reflect the monetization of oil revenue, which causes increase in money supply. This is exacerbated by the cash orientation of Nigerians and the penchant for carrying (and making payments with) lots of cash. Movements in inflation rates have been erratic but observed (not statistically proved though) to correlate with oil revenue pattern. Inflation have long recognized amongst others as one of the major factors that could derail the economy of any country. In Nigeria, the problem of inflation has caused the monetary authority to seek remedies on a continual basis. Therefore, studying the impact of macroeconomic factors such as the rate of inflation on oil price performance has implications for investors and policy makers (Corrado and Jordan 2002). Since early 1970's, inflation rates in Nigeria have been highly unstable; the high inflationary change was in excess of 30 percent. This is evident in the high correlation of money supply growth and high inflation due to the fact that real economic growth is less in real term to money growth. This can be observed from the growth in money supply and some structural factors such as; supply shocks arising from famine, unfavorable terms of trade and devaluation of currency. Furthermore, Structural Adjustment Program (SAP) introduced by the government in the late 1980's also accounted for the increase in the price level in the economy. Consequently, inflation in Nigeria has overtime responded to structural changes. These changes can be characterized into four periods based on the pattern and events that occur in that period.

The first period of inflationary increase in Nigeria was noticed from 1974 to 1976; inflation increased by 30 percent. This inflationary pressure was as a result of the following: high cost of agricultural produce caused by drought in the Northern part of Nigeria, excessive oil revenue 
monetization, increase in wage rate based on the recommendation of the Udoji commission of 1974 and political instability.

The second period was from 1983 to 1985 when the inflation rate reached 40 percent. This period noticed a very little economic growth, The Nigerian government was under intense pressure from debtor groups to accept International Monetary Fund conditionality's of devaluation of the domestic currency because government debt has increased above 70 percent while excess money growth was around 41 and 43 percent. This period also witnessed poor external trade performance (CBN, 2006).

The third period was from 1987 to 1989 when the inflation rate hovered around 35 percent. During this period, the economy experienced high inflationary pressure brought about by fiscal expansion noticed in the 1988 budget, the debt for equity swap conversion method adopted by the Government of Nigeria and the drastic contraction in monetary policy, all accounted for this change that span through to the early 1990's. Finally, the fourth period occurred between 1993 and 2000, as a result of fiscal deficit expansion which caused a 70 percent increase in the money supply with a knock-on effect on domestic credit to the private sector of the economy (CBN, 2006).

However, the persistent instability of crude oil prices in the global market has been revealed to have adversely affected macroeconomic performance of the Nigerian economy owing to the fact that Nigeria is a monoculture economy which is heavily dependent on crude oil export for its foreign earnings. Crude oil price instability has been found to affect production cost of foreign firms and since Nigeria is import dependent, an increase in crude oil prices makes imported goods to be very expensive which is in turn transmitted to domestic prices by raising the general price level (Mba-Afolabi, 1999; Labys, 2006; Nwosu, 2009; Arinze, 2011; Runl, 2011; Bobai, 2012). From 1990 to 2011, the prices of crude were reviewed more than ten times. The adjustment in 2000 under the democratically elected government marked a turning point in the economy as petrol moved up to N30 per litre, diesel to N29 and kerosene to N27 Runl (2011). According to the government, the upward review of domestic prices of petroleum products was necessitated by the high spot market price of crude oil and the need for higher margins for the Nigerian National Petroleum Corporation (NNPC) to meet operational and capital costs. Using Philips curve framework, Hooker (1996, 2002), LeBlanc and Chinn (2004), Blanchard and Gali (2007), Valcarcel and Wohar (2013) conclude that in countries such as the US, Japan, UK, Germany, France, Italy, the effect of oil prices on inflation and economic activity has dropped substantially over the time. The major argument for declining role of oil prices are effective monetary policy responses to unanticipated shocks, less rigid labor markets and lower energy intensity of industries. Additionally, some studies reveal an asymmetric pattern in oil price fluctuations, which means that although oil price hikes lead to a rise in domestic inflation even in negligible amount, on the hand, an oil price decline does not yield any conclusive results (Lown and Rich, 1997).

\section{LITERATURE REVIEW}

Nigeria also exhibits higher sensitivity to oil price volatility. Using the ARDL methodology in the Phillips curve framework, the authors estimate that 1 percent increase in oil prices lead to 0.04 percent increase in domestic inflation in the short run and 0.06 percent rise in the long run (Adeniyi and others, 2012). 
Katsuya Ito (2008) examines how much oil prices affect macroeconomic environment using VEC model for the period of 1997:1-2007:4 in Russia. His findings show that inflation would increase by 0.36 percent if oil prices rise by 1 percent. The similar findings are obtained for Kazakhstan by concluding negative reaction of all macroeconomic variables to oil price fluctuations (Gronwald et al.2009). Farzanegan and Markwardt (2009) analyze the dynamic relationship between oil price shocks and macroeconomic variables in Iran by using impulse response and variance decomposition approach.Their findings point out that both positive and negative oil price shocks raise inflation significantly.

The main conclusion of aforementioned researches is that oil price shocks exert influence on domestic inflation through two main channels. The fiscal channel operates through government expenditures that are funded by oil revenues and the cost channel works through the price of imported goods and services. Intuitively, in times of oil price hikes, budget expenditures rise and aggregate demand is boosted in the country. On the contrary, falling oil prices hurt the terms of trade through more expensive imports and reduced budget expenditures.

Existing literature makes such distinction between two channels only theoretically for some oil exporters; however empirically no paper has ever tried to assess the role of each channel. To our knowledge, this is the first study that applies the methodology a la Sims and Zha (1995) to measure the relative importance of different channels.

Labys (2006) observes that higher oil prices can lead to higher inflation, lower corporate profits, higher unemployment and reduced national economic growth. Higher price volatility can lead to a reduction in investment, leading in turn to a long term reduction in supply, higher prices, and even reduced macroeconomic activity. Regnier (2007) found that oil and energy price volatility increased following the 1973 oil crisis. This increase has been accompanied by an increase in price volatility for all commodities. In the late $1970 \mathrm{~s}$, however, price volatility for most products returned to pre-1973 levels, while oil price volatility continued to increase, while Raymond.

(2010) which looked at the effect of price changes of petroleum products in the short and long run and the factors responsible for the changes itself also found that petroleum products prices have significant effect on the economy in the long run.

Nwosu (2009) researched into the impact of fuel price on inflation. The study employed the variance Autoregressive analysis to assess the relative contribution of fuel price on inflation. Available quarterly data series spanning a period of 1995 to 2008 was analysed. Result showed a positive relationship between fuel price and inflation and therefore advocated that the policy of subsidizing fuel price should continue in Nigeria so as to help cushion the economy from the adverse effects of oil-price shock. Orgunbodede et al (2010) studied petroleum price crisis and the Nigerian public transportation system. The study claimed that incessant petroleum products price hike led to crisis and industrial actions in the country. They used perception scale on a 4-point Likert scale to elicit response from the operators of public passenger transport system using a 4-point Likert scale.

The Mean Weight Value (MWV) was compared with the Group Arithmetic Mean (GAM) of each group and the results indicated that price increase significantly increased transport fare and fuel hoarding in Nigeria. 
Arinze (2011) focused on the impact of oil price on the Nigerian economy. The study contends that upward adjustments of petroleum products prices have resulted in inflation, high cost of living, and inequitable income distribution in Nigeria between 1978 and 2007. It also found that the various Nigerian regimes increased fuel prices a total of 18 times within this period with most of the increase occurring between 1990 and 2007 where prices were adjusted, twice a year, sometimes. The study revealed that petroleum price increase spur inflation rate to increase also.It therefore recommended diversification of the Nigerian economy to curb macroeconomic instability which may arise from over dependence on crude oil.

Bobai (2012) analysed the relationship between petroleum prices and inflation in Nigeria. It focused on the impact of petroleum product price increase on the Nigerian economy from 1990 to 2011. Employing the empirical econometric analysis approach and using variables like inflation rate and petroleum prices, the results shows that positive relationship exists between PMS, AGO and inflation. It however found PMS to exert higher effect on inflation than AGO, while negative relationship exists between inflation and DPK. The overall effect clearly indicates that increase in petroleum product price contributes significantly to the rate of inflation in Nigeria.

Ehinomeri and Adeleke (2012) shared their views that the distribution of petroleum products in the Nigerian economy is fraught with complex problems resulting sometimes in products outages, inflated price of products and contentions on the pump price of products. Their research examines the various issues regarding the distribution of products and recommends that the downstream activities of the industry be completely deregulated to allow private sector and entrepreneur's full participations in the distribution of the products. Their findings hypothesized that the participation of entrepreneurs will drive effectiveness into the sector. This effectiveness will bring down operations cost as well as the price level for the benefit of all the stake-holders in the country.

Akinleye and Ekpo (2013) examined the macroeconomic implications of oil price shocks on macroeconomic performance in Nigeria. The study employed the vector autoregressive estimation technique and observed that both positive and negative oil price shocks influence real government expenditure only in the long run rather than in the short run. It also found that positive rather than negative oil price shocks have stronger short and long run effects on real gross domestic product, thereby triggering inflationary pressure and domestic currency depreciation in the process as importation increases. The study posits that crude oil price shocks are capable of impeding economic growth only in the long run while raising general price levels marginally in the short run leading to exchange rate depreciation and high importation.

A number of studies have focused on emerging oil importing Asian and Sub-Saharan countries to investigate empirical and theoretical mechanism of oil price pass through. A study by Jongwanich and Donghyun (2011) concludes that the magnitude of oil price pass-through is limited in nine Southern and Southeast Asian countries. Subsidies and price controls by governments are major factors for mitigating or delaying the undesirable effects of oil price shocks to inflation. Using SVAR model for China for the period of 1998-2008, Tang, Wu and Zhang (2010) explain that a surge in oil prices reduces output and investment, and simultaneously raises inflation and interest rates. However, due to price controls in China, in the long run the effect of oil price changes on inflation is negligible. The empirical findings for 
Kenya show that $10 \%$ increase in oil prices lead to $0.5 \%$ upsurge in inflation rate in the shortrun and $1 \%$ in the long run (Kiptui, 2009).

Using recursive VAR for Turkey, Chen (2008) finds that the pass-through effect of oil prices on domestic CPI has increased over time. The higher import dependency and as a result, a substantial amount of current account deficit cause Turkey to be vulnerable to oil price and exchange rate fluctuations. Moreover, the ongoing growth rate of the economy creates higher demand for energy resources as most industries mainly depend on fuel energy (Dedeoglu and Kaya, 2014).

\section{METHODOLOGY AND DATA}

The main aim of this study is to examine crude oil fluctuation and inflation rate in Nigeria. This study employed quarterly time series data from 1980:1 to 2015:4. The data was obtained mainly from secondary sources such as; Central Bank of Nigeria Statistical Bulletin and EIA Short-Term outlook. Variables for which data was collected are; crude oil price (COP) inflation rate (INFL) and real exchange rate (REXCHR).

The Vector auto-regression (VAR) model was adopted as the fundamental model for this work to capture the evolution and the interdependencies between all the variables in the VAR model are treated symmetrically by including for each variable an equation explaining its evolution based on its own lags and the lags of all the other variables in the model.

To estimate the model, some tests were carried out which included: (i) Lag length selection; (ii) VAR stability tests (iii) VAR LM test for serial correlation (iv) the impulse response function and (v) Forecast Error Variance Decomposition. Correct specification of time series models requires that the data used are stationary. Thus, we shall use the Augmented Dickey-Fuller statistic to establish if there is unit root in our model or not. We also analyzed and forecasted macroeconomic activities, and traced the effects of unstable crude oil price and exchange rate in Nigeria.

\section{Model Specification}

For the purpose of analyzing and forecasting macroeconomic activities, and tracing the relationship between inflation and crude price fluctuation in Nigeria economy, simple smallscale VARs with sound theoretical foundation have proved to be as good as or better than large-scale structural equation systems. VAR models in addition to forecasting have been used to serve two primary functions: testing causality (weak exogeneity) and; studying the effects of policy shocks through impulse response characterization and forecast error variance decomposition. This study therefore estimated a vector autoregressive (VAR) model to trace the effect of crude price fluctuation on inflation in Nigeria. We specified the generalized VAR model as:

$\mathrm{Y}_{\mathrm{t}}=\mu+\mathrm{A}_{1} \mathrm{y}_{\mathrm{t}-1}+\mathrm{A}_{2} \mathrm{y}_{\mathrm{t}-2}+\ldots+\mathrm{A}_{\mathrm{k}} \mathrm{y}_{\mathrm{t}-\mathrm{k}}+\epsilon_{\mathrm{t}}$

Where the $\boldsymbol{\epsilon}_{\mathrm{t}}=\left(\boldsymbol{\epsilon}_{1 \mathrm{t}}, \ldots, \boldsymbol{\epsilon}_{\mathrm{kt}}\right)^{\prime}$ form a sequence of independently identically distributed random Kvector with zero mean vector. Thus equation 3.1 can be arranged to obtain

$\mathrm{y}_{\mathrm{t}}=\mu+\sum \mathrm{A}_{\mathrm{i}} \mathrm{y}_{\mathrm{t}-\mathrm{l}}+\epsilon_{\mathrm{t}}$

$\mathrm{i}=1$

Where $y_{t}$ is a column vector of three (3) variables, that is yt $=[$ RCOP, INFL and REXCHR]' modeled in terms of its past values. $A_{i}$ are $\mathrm{kx} \mathrm{k}$ matrix of coefficients to be estimated, $\mu$ is a $\mathrm{kx}$ 1 vector of constants and $\epsilon_{t}$ is a vector of white noise processes. Where the covariance matrix $\Omega$ 
is assumed to be positive definite. Thus the $\epsilon^{\prime}$ s are serially uncorrelated but may be contemporaneously correlated. The lag length, $\mathrm{k}$ is determined empirically using the Akaike information criterion. The model with the lower Akaike value is selected. Therefore estimation was done by iteration starting with the maximum lag length identified using the information criteria until the optimum model is arrived at-that is until the model becomes stable (no modulus or eigenvalue lies outside the unit circle).

\section{RESULT AND DISCUSSION}

Empirical results of this research is presented in the tables and discussed below:

Table 1: Lag Order Selection Criteria

\begin{tabular}{|c|c|c|c|c|c|c|}
\hline & & & & & & \\
\hline Lag & $\log \mathrm{L}$ & LR & FPE & AIC & $\mathrm{SC}$ & HQ \\
\hline 0 & -904.9813 & $\mathrm{NA}$ & 168.6630 & 13.64151 & 13.83614 & 13.72060 \\
\hline 1 & -419.9676 & 926.5932 & 0.138537 & 6.536830 & 6.926092 & 6.695014 \\
\hline 2 & -389.9728 & 55.96052 & 0.101312 & 6.223474 & $6.807368^{*}$ & $6.460750 *$ \\
\hline 3 & -383.4238 & 11.92507 & 0.105175 & 6.260056 & 7.038580 & 6.576423 \\
\hline 4 & -369.9055 & 24.01014 & 0.098452 & 6.192619 & 7.165774 & 6.588078 \\
\hline 5 & -360.7640 & 15.82704 & 0.098448 & 6.190507 & 7.358293 & 6.665058 \\
\hline 6 & -351.6957 & 15.29421 & 0.098635 & 6.189489 & 7.551906 & 6.743131 \\
\hline 7 & -336.0710 & $25.65255^{*}$ & $0.089698^{*}$ & $6.090612 *$ & 7.647660 & 6.723346 \\
\hline 8 & -330.8380 & 8.357123 & 0.095367 & 6.146836 & 7.898516 & 6.858662 \\
\hline 9 & -323.4980 & 11.39341 & 0.098384 & 6.171613 & 8.117923 & 6.962530 \\
\hline 10 & -314.1403 & 14.10646 & 0.098633 & 6.166273 & 8.307214 & 7.036282 \\
\hline$*$ indic & es lag order & lected by the & criterion & & & \\
\hline $\begin{array}{l}\text { LR: se } \\
\text { level) }\end{array}$ & ntial mod & d LR test & tatistic (eac & test at $5 \%$ & & \\
\hline FPE: F & al prediction & rror & & & & \\
\hline AIC: A & aike informa & on criterion & & & & \\
\hline $\mathrm{SC}: \mathrm{Sc}$ & varz informa & on criterion & & & & \\
\hline $\begin{array}{l}\text { HQ: H } \\
\text { Source }\end{array}$ & $\begin{array}{l}\text { nan-Quinn i } \\
\text { uuthor's com }\end{array}$ & $\begin{array}{l}\text { ormation cr } \\
\text { utation. }\end{array}$ & erion & & & \\
\hline
\end{tabular}

The result in table 1 showing the maximum lag length determination estimated via the lag order selection criteria. The result shows that the optimum lag is lag seven (7) since most of the criteria - LR, FPE, and AIC showed the seventh lag to be the optimum lag length the VAR(7) model was estimated. It is important for the VAR model has to be dynamically stable to be fit 
for policy purposes. Thus the Roots of Characteristic Polynomial were examined for stability and the estimated results presented on table 2

Table 2: Roots of Characteristic Polynomial

\begin{tabular}{|l|c|}
\hline \multicolumn{1}{|c|}{ Root } & Modulus \\
\hline 0.901547 & 0.901547 \\
\hline 0.866146 & 0.866146 \\
\hline 0.512477 & 0.512477 \\
\hline-0.360334 & 0.360334 \\
\hline $0.028036-0.328104 \mathrm{i}$ & 0.329300 \\
\hline $0.028036+0.328104 \mathrm{i}$ & 0.329300 \\
\hline $\begin{array}{l}\text { No root lies outside the unit circ } \\
\text { VAR satisfies the stability condi }\end{array}$ & \\
\hline
\end{tabular}

Source: Author's computation

The root of characteristics polynomial reveals that no root lies outside the unit cycle (Modulus) as such the VAR model satisfies the stability condition and the model is dynamically stable and appropriate for policy formulation.

Having determined the stability of the VAR model we proceed to ascertain if the model has the problem of autocorrelation. The test result is presented and discussed below:

Table 3: Autocorrelation LM Test

\begin{tabular}{|c|c|c|}
\hline Lags & LM-Stat & Prob \\
\hline \hline 1 & 112.9807 & 0.2940 \\
\hline 2 & 11.10352 & 0.2687 \\
\hline 3 & 9.890561 & 0.3594 \\
\hline 4 & 4.332807 & 0.8882 \\
\hline 5 & 9.106954 & 0.4275 \\
\hline 6 & 12.14193 & 0.2054 \\
\hline 7 & 14.55587 & 0.1039 \\
\hline 8 & 5.333679 & 0.8043 \\
\hline 9 & 8.756664 & 0.4600 \\
\hline 10 & 5.799494 & 0.7598 \\
\hline 11 & 4.361510 & 0.8861 \\
\hline 12 & 8.920753 & 0.4446 \\
\hline Probs from chi-square with 9 df. \\
\hline
\end{tabular}

Source: Author's computation. 
The test result for autocorrelation as evident in table 3 shows that the model do not suffer for serial correlation up to the twelfth lag i.e lag(12); thus serial correlation is not present in the model.

Table 4: Forecast Error Variance Decomposition

\begin{tabular}{|c|c|c|c|c|}
\hline & & & & \\
\hline Period & S.E. & D(INFL) & D(RCOP) & D(REXCHR) \\
\hline & & & & \\
\hline 1 & 5.529101 & 35.30874 & 64.69126 & 0.000000 \\
\hline 2 & 6.666022 & 25.02354 & 74.87191 & 0.104547 \\
\hline 3 & 6.962528 & 23.36809 & 76.05708 & 0.574826 \\
\hline 4 & 7.114482 & 22.92249 & 76.09794 & 0.979570 \\
\hline 5 & 7.238158 & 22.74861 & 75.88122 & 1.370174 \\
\hline 6 & 7.349976 & 22.81654 & 75.44955 & 1.733914 \\
\hline 7 & 7.453455 & 23.02262 & 74.90263 & 2.074748 \\
\hline 8 & 7.551705 & 23.28569 & 74.32765 & 2.386660 \\
\hline 9 & 7.646690 & 23.57309 & 73.75464 & 2.672275 \\
\hline 10 & 7.739311 & 23.87193 & 73.19392 & 2.934155 \\
\hline
\end{tabular}

Cholesky Ordering: D(INFL) D(RCOP) D(REXCHR)

Source: Author's computation.

The impulse response graphs (see appendix1). The graphs revealed that the impact of inflation on innovations in the oil price shock was positive in the first and second forecast periods became negative between the third periods and fourth periods did not die out in the long run. While the impact of exchange rate on oil price fluctuation was zero in the first forecast period but increased gradually from thence and did not die out in the long-run. The impact of shocks in oil price on own innovations was very high in the first forecast horizon but declined rapidly and became steady without dying out in the long run. The implication is that as fluctuations in oil price is negatively related to inflation - as oil price is fall inflation also fall within the same forecast period and when oil price became steady over the long run inflation also became negatively steady in the long run.

The result in table 5 shows real oil price (RCOP) forecast error variance decomposition which measures the percentage of the forecast error variance of RCOP that is explained by own and innovations in other variables over the forecast horizon. The results revealed that in the first forecast horizon 64 percent of the forecast variance is explained by own innovation while innovations in inflation account for 35 percent and exchange rate none. However, oil price in the long - run, own innovations did not decline rather increase rapidly and explained 73.13 percent in the tenth horizon while innovations in exchange rate (REXCHR) explained 2.94 percent. Inflation (INFL) that explained most of the variance in oil price fluctuations in the long - run (23.87 percent). This result implies that inflation as a macroeconomic variable has a 
negative reaction to oil price fluctuations oil price shocks exert influence on domestic inflation through two main channels. The fiscal channel operates through government expenditures that are funded by oil revenues and the cost channel works through the price of imported goods and services. The findings of this study is consistent with that of Katsuya, (2008); Gronwald et. al (200); and Farzanegan and Markwardt (2009).

\section{CONCLUSION AND RECOMMENDATIONS}

This research is aimed to determine the relationship between inflation and oil price fluctuations in Nigeria using a small-scale vector autoregressive model analysis to test the relationship. Empirically the impulsion response result of this study shows that the response of inflation to oil price fluctuation is that as oil prices falls inflation fall also and a stable and positive oil price results in a stable negative inflation rate, thus the relationship between them inflation and oil price fluctuation is negative. The variance decomposition result shows that oil price explains inflation as well as inflation causes reasonable changes in oil price though the cost channels which has a certain role for spreading the effects of oil price shocks into inflation in the domestic economy. This study therefore recommends that the cost channels transmitting should weakened by further diversification of the Nigeria economy and enhancement of import substitution strategies. To facilitate the monetary authority in achieving lower inflation and stable economic growth targets counter-cyclical fiscal policies and effectively binding fiscal rules should be formulated and implem

\section{REFFERENCES}

Adedipe, B. (2004). The impact of oil on Nigeria's economic policy formulation; Paper presented at the Conference of the Nigeria Economic Summit Group. Lagos, June 16 - 17.

Akinleye S.O. \& Ekpo S. (2013), "Oil price shocks and macroeconomic performance in Nigeria”, economía mexicana nueva época, vol. 2, 2013, pp. 565-624.

Arinze P.E. (2011), "The impact of oil price on the Nigerian economy", JORIND, 9: 211-215.

Bobai F.D. (2012), "An Analysis of the Relationship between Petroleum Prices and Inflation in Nigeria”, International Journal of Business and Commerce, 1(12): 1-7.

Bernanke, B. S., Gertler, M., and Watson, M., (1997). "Systematic Monetary Policy and the Effects of Oil Price Shocks." Brookings Papers on Economic Activity, 1997(1), 91-157.

Blanchard, O. J. and Galí, J. (2007). “The Macroeconomic Effects of Oil Price Shocks: Why are the 2000s so different from the 1970s?" University of Chicago Press. International Dimensions of Monetary Policy, pp. 373 - 421.

Central Bank of Nigeria (2003). Issues in fiscal management implications for monetary policy in Nigeria. CBN Third Annual Monetary Policy Conference proceedings. Lagos. December 11-13. pp.205-230.

Central Bank of Nigeria (2006) Annual Statement and Statement of Account, CBN Publications

Central Bank of Nigeria (2015) Annual Statement and Statement of Account, CBN Publications

Chen, S. S. (2008). “Oil Price Pass-Through into Inflation.” Social Science Research Network, online access.

Dedeoğlu, D., and Kaya, H. (2014). "Pass-through of oil prices to domestic prices: Evidence from an oil-hungry but oil-poor emerging market." Economic Modeling, 43, issue C, p. 67-74.

Einomeri, A. and D. O. Adeleke, (2012) Global Crisis Facing Petroleum Products Distribution. Intel Publications Ltd.

Energy Information Administration (EIA) (2009). Country analysis briefs on Nigeria, official energy statistics from the United States Government. Retrieved online from http://www.eia.doe.gov/emeu/cabs/OPEC Revenues/Factsheet.html.

Farzanegan, M. R. and Markwardt, G. (2008). "The effects of oil price shocks on the Iranian economy”. Dresden University of Technology Dresden Discussion Paper Series in Economics 15/08.

Gronwald, M., Mayr, J. and Orazbayev, S. (2009). "Estimating the effects of oil price shocks on the 
Kazakh economy." Ifo Institute for Economic Research at the University of Munich. Ifo Working Paper No.81.

Labys W.C. (2006), “Globalization, Oil Price Volatility, and the U.S. Economy”, Regional Research Institute, Natural Resource Economics Program, West Virginia University Morgantown, WV, 265066108

Mba-Afolabi, J. (1999) “The Oil Price of Hike Blunder”, Newswatch, January 18, pp. 8 - 16.

Nwosu, C.P. (2009) "Import of Fuel Prices on Inflation: Evidences from Nigeria”. Research Department, Central Bank of Nigeria, http://ssm.com/abstract $=1365820$

Oil \& Gas Downstream Industry Report (2008). A Publication of Agusto \& Co; Research, Credit Ratings, Credit Risk Management

Onwioduokitanda E. A. and Adenuga 0. 2000 "Empirical Analysis of the Demand for Petroleum Products in Nigeria”. C.B.N 2000 Journal Publication pp 33-57.

Orgunbodede, E.F, Ilesanmi, A.O. and Olurankinsa, F. (2010): Petroleum Price Crisis and the

UNCTAD, (2005). The Exposure of African governments to the volatility of International Oil Prices, and what to Do About It. AU Extraordinary Conference of Ministers of Trade on African Commodities Arusha, Tanzania, 21-24 November 2005, UNITED NATIONS, New York.

World Bank Data and Statistics. World Development Indicators (WDI), 2013. www.brics5.co.za/fifth-bricssummit-declaration-and-action-plan/(Accessed 20 July 2013) 


\section{Figure 3}

Response of CPI to Cholesky

One S.D. Innovations

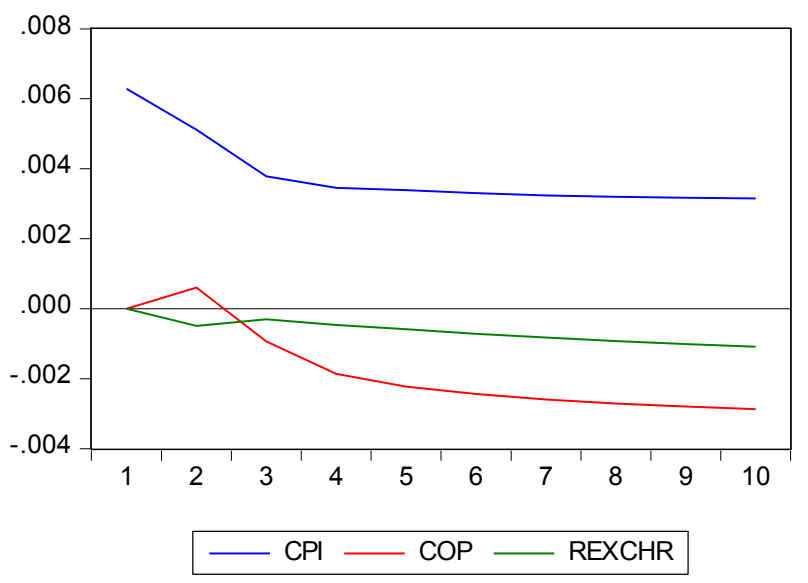

Response of COP to Cholesky

One S.D. Innovations

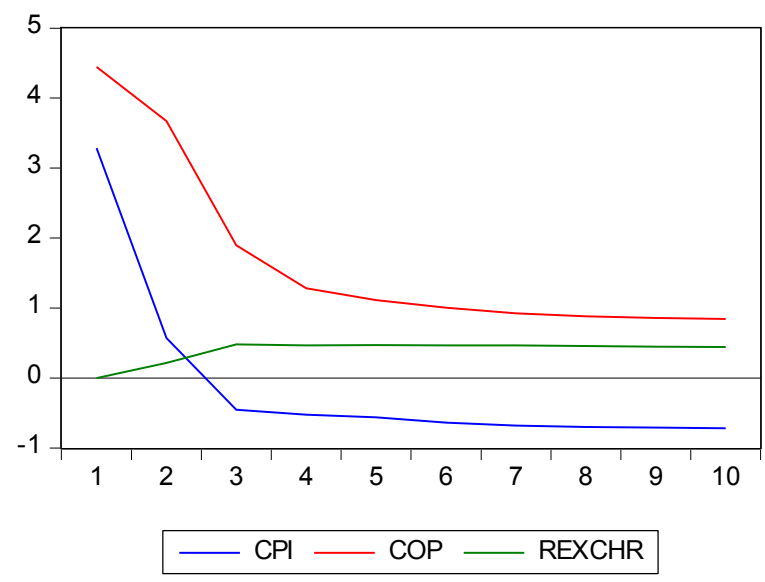

Response of REXCHR to Cholesky One S.D. Innovations

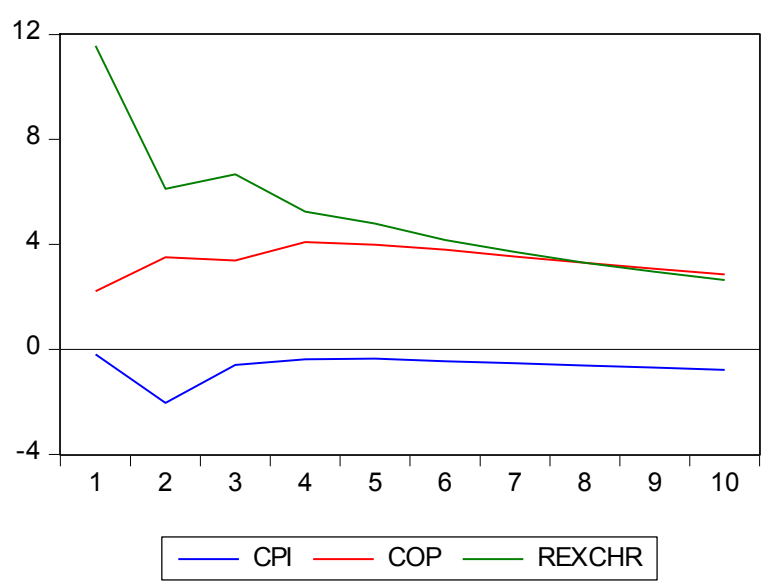

